\title{
Do legal origins impact infant mortality? Evidence from sub-Saharan Africa
}

\author{
Nourhan Hashish \\ Sorbonne School of Economics
}

Université Paris 1 - UFR 02 Sciences Économiques, Paris

\author{
Keywords \\ Institutions, Economic Development, Health Economics, Infant Mortality.
}

\begin{abstract}
This study investigates the possible link between the legal origins of 27 sub-Saharan African countries and the health status of the population proxied by infant mortality rates (IMR). IMR is broken down into three categories: neonatal mortality, post-neonatal mortality, and infant mortality. The data is collected through the Demographic Health Survey DHS. Further corresponding geospatial covariates are being used to implement a Regression Discontinuity design (RD) depicting the impact of civil and common law on the three categories of IMR. The RD framework entails comparing the child mortality of the individuals close to the borders of another country with a different legal origin. Additional regression tables are estimated to compare their results with that of the $R D$. Both the $R D$ and the table results provide enough evidence that post-neonatal and infant mortality are more abundant under civil law regimes than under common law ones signaling at better general health conditions under the latter. However, neonatal mortality does not seem to be impacted by legal origins
\end{abstract}

\section{Introduction}

According to the recently declared universal agenda of the Sustainable Development Goals (SDGs), there is an emphasis on controlling the worldwide infant mortality phenomena by 2030 (Child Survival SDG). However, the United Nations Children's Fund predicted that around two-thirds of sub-Saharan African countries are at a high risk of not meeting these goals (UNICEF). Following the declarations of the UNICEF, questions are raised about possible root causes that might lead to the highly prevalent infant mortality rates in the sub-Saharan African countries. More specifically, these questions pertain to the role of institutions in the persistence of the high child mortality rates in this African region. Infant mortality rates (IMR) have been considered as indicator of the population health. However, they were criticized for giving a narrow idea about the health of the people. According to Reidpath and Allotey (2003) IMR of a country give an overview of the health conditions of not just the children but also the whole population. Consequently, using IMR in this study stems from 2 main considerations: the first, is that infant mortality is a major problem in sub-Saharan Africa in the realm of the underdevelopment of this region. The second is that IMR is a valid signal of the overall well-being of the population in each state. In this regard, the proposed research paper is focusing on sub-Saharan African countries to examine the possible linkage between legal institutions and infant mortality.

The main added-value to the literature of the legal system and health outcomes is basically that this is the first micro-level study that focuses on the individual-level impact of the colonial legal institutions on the child mortality phenomena as an index of the public health status of the people. This study makes use of the Demographic Health Survey (DHS), their geospatial covariates and the Ethnographic Atlas data to find a plausible answer to the research question. The empirical strategy consists of running Regression Discontinuity design (RD) graphs and regression tables that aim at comparing the outcome variables of the individuals along the national borders of the 27 sub-Saharan African countries that have different legal origins. As per the results, it can be inferred that the health outcomes of the individuals are generally better under a common law regime rather than a civil law one unlike what is claimed by the macro-level studies.

\section{Related literature}

There are two main types of legal institutions in African countries -according to whether their former colonizer was French or English- namely civil and common law. The civil law originated from the French 
legal system while the common law emerged from that of the English. These legal origins have an influence on the institutions and the eco- nomic outcomes of the states persisting up until today, long after sub-Saharan Africa regained its independence. La Porta, R., Lopez-de Silanes, F., and Shleifer, A. (2008) state that these two types of legal institutions coexist in the sub-Saharan African countries and managed to have an impact on the economic outcomes of the people living in this region. Acemoglu and Johnson (2003) were the first to disentangle the link between legal institutions and economic outcomes in terms of the citizens' property rights under a legal framework protecting them against expropriation by the government or elites. Additionally, La Porta, R., Lopez-de Silanes, F., and Shleifer, A. (2008) as well as Michalopoulos and Papaioannou (2013) postulate that there is a link between legal institutions and the regional development of the states at the macro-level. Michalopoulos and Papaioannou (2013) attempt to interpret the role of the pre-colonial ethnic institutions in shaping the regional development within African countries. Their results signal that the more centralized and hierarchical the pre-colonial institutions were, the higher the regional development was.

Scanlon (2016) introduced a new feature in the investigation of the various impacts of the legal origins through analyzing the health outcomes of the legal institutions at the macro level. Scanlon (2016) results provide enough evidence supporting the premises that citizens under civil law countries have better health outcomes in terms of immunization, sanitation, pregnancy, and infant mortality. The main takeaway from these results is that better health outcomes in countries with civil law regimes are thanks to the decentralization of government expenditure on health following the colonial rule.

Heaton (2015) further investigates a micro-level stream of the health outcomes and legal origins literature documenting that women's social and economic empowerment through legal institutions will not only affect them, but will also have a positive impact on the health status of their children. Anderson (2018) attempts to find if the existent legal institutions have an impact on the disease outcomes of the individuals, her results show that HIV prevalence rates in females are much higher in common law countries than in civil law ones. The driver of the higher HIV infection rates among females in common law countries is the low level of woman empowerment. In fact, Hallward- Driemeier and Hasan (2012) demonstrate that under common law, there is a separate ownership of assets following the British common law system, that formally approves the "Married Women's Property Act" of 1882. However, under civil law, there is a high protection of women in case of divorce and a joint ownership of property between married couples. Anderson (2018) rests on these differences to demonstrate the idea that given women's rights under civil law, they are more empowered compared to women under common law. Women under civil law are have a high bargaining power in the household and ask for safer sexual practices which protects them against HIV infection.

In this context, the main question investigated in this research paper is whether the legal origins of the sub-Saharan African countries have an impact on the prevalence of infant mortality rates. The main premise of this research is the fact that there are intrinsic differences between countries that adopt common law based on Anderson (2018) find- ings and Hallward-Driemeier and Hasan (2012) literature. This study is complementary to the literature of Anderson (2018) and Scanlon (2016) since Anderson was focusing on the HIV incidence specifically without much attention to the general public health out- comes of the individuals while Scanlon (2016) looks at the general health outcomes at the macro level to have a comprehensive overview of the impact of legal origins on health outcomes. The intended contribution to the literature in this study entails examining the health outcomes of the legal origins at the micro-level since the literature only provides them at the macro-level.

\section{Empirical strategy \\ Common Law without Interaction Terms}

Following Anderson (2018), 27 countries will be investigated in this study. As per Michalopoulos and Papaioannou (2013) as well as Anderson (2018), this paper will follow a Regression Discontinuity design (RD) framework where the focus will be on country pairs with dissimilar legal origins. The individuals living close to national frontiers of a country with a different legal origin will be compared: individuals under civil law are part of the control group while those under common law are considered as the treatment group. The RD framework is presented in the following regression: 


$$
\mathrm{Y}_{\text {rcepi }}=a_{0}+a_{1} l_{r c}+a_{2} X_{r c}+a_{3} X_{r c e p}+a_{4} X_{r c e p i}+f\left(B D_{r e c p}\right)+\sigma_{e}+\gamma_{r}+\theta_{t}+s_{r c e p i}
$$

The dependent variable will be a binary outcome indicating if the child is alive or not for children living in region $\mathrm{r}$, country $\mathrm{c}$ and pixel $\mathrm{p}$. There will be three types of dependent variables examined according to the age the child at death: neonatal, post-neonatal and infant. $L_{r c}$ is a dummy that is equal to one to indicate a common law system while $X_{r c}$ are there to capture the region and the country level characteristics such as the geographic, demographic, environmental, and disease characteristics. Additional pixel level controls $X_{\text {rcep }}$ are included such as population density, malaria prevalence, light intensity, the distance to the national border, to the sea and the capital per each region, country, ethnicity, and pixel. A set of individual-level controls $X_{\text {rcepi }}$ for both the mother and the child are added such as the mother's age during childbirth, her education level. The child control variables are mainly the birth order of the child and the birth interval between the children and their siblings. The variable $\sigma_{e}$ controls for ethnicity-level characteristics such as the inheritance rules, the style of marriage (monogamous or not) and the jurisdictional setting within ethnicities. Moreover, a second-order RD polynomial $f\left(B D_{\text {recp }}\right)$ is added to account for the distance between the centroid of every pixel and the closest national frontier. The variable $\gamma_{r}$ indicates the region fixed effect; if the sub- Saharan African country belongs to southern, central, western, or eastern region. There is a year dummy $\theta_{t}$ to capture the different years of the surveys. The RD framework is intended to provide the causal impact of legal origins on the three levels of child mortality. In a nutshell, these controls are chosen as they are said have an impact on the spread of child mortality phenomena in the region at the different levels: individual, country and ethnicity.

The results are a set of RD graphs that depict the relationship between legal origins, the variable of interest, and each of the three dependent variables mentioned above. The variable of interest will be the dummy variable that specifies the legal institution--whether it is common or civil law- under which each country falls. This equation will be estimated three times with a different category of child mortality to disentangle the effect of legal institutions on the different levels of child mortality: neonatal, Post- neonatal and infant mortality that are proxies of the health stance of the citizens of the sub-Saharan African region. Following this estimation strategy, there will be three separate RD graphs to visualize the estimated relationship between the variable of interest and the dependent variable. It is important to note that the demonstrated RD graphs do not include any time dimensions, they fall under the cross-sectional RD. Because of the nature of this study that incorporates time invariant legal origins, the data is structured in such a way -cross sectional- so as to be able to analyze the effect of the time invariant variable in question that is common law.

\section{Data}

The data are broken down into four levels: Pixel, Ethnicity, Country, and Individual levels. The focus of this study is on the child mortality incidence of 27 sub-Saharan African countries susceptible to high levels of infant mortality. Therefore, the individual is the unit of analysis in this framework. Among the 27 sub-Saharan African countries studied, 4 have frontier countries with no different legal origins which are Cameroon, Gabon, Mali, Senegal while Lesotho and Madagascar do not have neighbouring countries to be- gin with according to Anderson (2018).

\section{Pixel, Ethnicity and Country Level Data}

To implement the RD framework, this study makes use of sub-Saharan African countries characterized by a neighbouring country with a different legal origin as presented in

Table-1

\begin{tabular}{|l|l|}
\hline Common law & Civil Law \\
\hline Ghana & Burkino Faso \\
Tanzania & Burundi \\
Ghana & Togo \\
Tanzania & Rwanda \\
Uganda & Rwanda \\
Zimbabwe & Namibia \\
\hline
\end{tabular}




\begin{tabular}{|l|l|}
\hline Zambia & Namibia \\
Zambia & Mozambique \\
Swaziland & Mozambique \\
Malawi & Mozambique \\
Zimbabwe & Mozambique \\
Sierre Leone & Guinea \\
Liberia & Guinea \\
Kenya & Ethiopia \\
Liberia & Ivory Coast \\
Ghana & Ivory Coast \\
Uganda & Democratic Republic of the Congo \\
Zambia & Democratic Republic of the Congo \\
Tanzania & Democratic Republic of the Congo \\
\hline
\end{tabular}

Table 1: Country Pairs of different Legal origins

The country level variables are extracted from the Demographic Health Survey (DHS) that is an initiative by the United States Agency for International Development (USAID) in order to keep track of the health stance and the population trends of developing countries (IndexMundi). The variables used in this study emphasize on the type of legal origin the country has, whether it falls under the common law or the civil law regime as per the classification of Anderson (2018). Other variables reflect the overall economic and political circumstances such as the GDP per capita, the different regions where the people reside be it the northern, southern, western, eastern, or central parts of Africa.

The Pixel level variables are acquired from the Ethnographic Atlas that consists of collecting ethnographic information for a number of ethnic groups and has various

ethnographic variables as per Michalopoulos and Papaioannou (2013) description. More- over, the spatial distribution of the ethnicities is the same and did not change much throughout the years. The main pixel level variables are the existence of diamond mines, of petroleum fields, the elevation of a given ethnicity, the inheritance rules of the real and movable property are also added, the political integration of the ethnicities, their mode of marriage whether it is monogamous or polygamous as well as the jurisdictional hierarchy in each ethnicity. The jurisdictional hierarchy indicates the extent of the complexity of political system in the society beyond the local level. Also, the political centralization variable as in the degree to which the government's power is concentrated. In this context, the pixels used for the grids will manifest different sizes depending on the latitude and the longitude so the distances in kilometers are approximated.

\section{Individual-Level Data}

The individual level data are from the DHS survey that collect data for children under age 5 and women of age 15 to 49 through a number of questionnaires. The women eligible for the survey respond to questions not only related to them as women but also to their maternal health and their birth record such as listing their number of children dead or alive, their sex, their age, birth dates, immunization, child health, and nutrition (Guide to DHS). In addition, some variables are also included to indicate the general household characteristics in this study such as the place of residence to indicate if the child is born in a rural or urban area or born to a poor of a wealthy family which might have an impact their health and on their chances of having access to health care services. The DHS surveys were gathered for the 27 SSA countries covering the period from 1999 to 2014 for each country for a comprehensive analysis. The GPS data at the

individual level is obtained from the DHS program Geospatial covariates that allocates to each individual a set of variables such as the average satellite light density and the distance to the national border that reflects the geodesic distance of the centroid of each pixel to the closest international border and the nearest sea as well as the land surface area as well (The DHS Program). The GPS data are allocated 
to the individual level data which are then merged with that of the ethnicity-country level to conduct this analysis.

\section{Results}

The descriptive statistics of the 3 levels of the data in table 2 shows the dummy variables of 3 categories of child mortality: infant mortality, post-neonatal and neonatal mortality. The overall number of observations in this data set is 3,781,758. Following Pathania (2014), infant mortality refers to the children who die after reaching 12 months of age, post-neonatal mortality refers to the children who die during 0 to 11 months of age while neonatal mortality refers to children who die exactly at 0 months of age. The infant mortality dummy variable has a higher mean value than the two other types of mortality, of 0.06 while that of post-neonatal and neonatal have mean values of 0.03 each. The average age of mothers during childbirth is 29 years old while that of uneducated mothers is 0.40 . The average birth interval of the mothers is around 42 months while the birth order is around 3 children. These individual level variables give a general idea about the overall characteristics of the mothers and the children.

\begin{tabular}{lccccc}
\hline Variables & Mean & P50 & SD & Min & Max \\
\hline Neonatal Mortality & 0.06 & 0.00 & 0.20 & 0.00 & 1.00 \\
Postnatal Mortality & 0.03 & 0.00 & 0.16 & 0.00 & 1.00 \\
Infant Mortality & 0.06 & 0.00 & 0.23 & 0.00 & 1.00 \\
Common Law & 0.51 & 1.00 & 0.50 & 0.00 & 1.00 \\
Mother's Age & 29.00 & 28.00 & 7.04 & 15.00 & 49.00 \\
Population Density & 50.51 & 28.95 & 77.78 & 0.00 & 1689.62 \\
Domestic Organization & 5.49 & 5.00 & 2.03 & 0.00 & 8.00 \\
Marital Composition: Monogamy and Polygamy & 4.59 & 5.00 & 1.45 & 0.00 & 6.00 \\
Subsistence Economy & 6.06 & 6.00 & 0.83 & 1.00 & 9.00 \\
Ethnicity & 25.31 & 8.00 & 38.54 & 0.00 & 999.00 \\
Birth Order & 3.52 & 3.00 & 2.40 & 1.00 & 18.00 \\
Births Interval & 42.41 & 36.00 & 25.12 & 6.00 & 327.00 \\
Births for Uneducated Women & 0.40 & 0.00 & 0.49 & 0.00 & 1.00 \\
Distance to Capital & 0.61 & 0.47 & 0.48 & 0.01 & 1.88 \\
Distance to Border & 0.09 & 0.06 & 0.10 & 0.00 & 0.54 \\
Distance to Sea & 0.65 & 0.57 & 0.47 & 0.00 & 1.67 \\
Malaria suitability & 0.84 & 1.00 & 0.26 & 0.00 & 1.00 \\
Diamond Mine & 0.14 & 0.00 & 0.34 & 0.00 & 1.00 \\
Petroleum Field & 0.01 & 0.00 & 0.09 & 0.00 & 1.00 \\
Land Suitability for Agriculture & 0.40 & 0.35 & 0.16 & 0.00 & 0.98 \\
Mean Elevation & 0.54 & 0.47 & 0.40 & 0.00 & 2.18 \\
Land Area & 17.94 & 10.50 & 20.81 & 0.11 & 408.99 \\
Region: South & 0.03 & 0.00 & 0.17 & 0.00 & 1.00 \\
Region: East & 0.10 & 0.00 & 0.30 & 0.00 & 1.00 \\
Region: Central & 0.54 & 1.00 & 0.50 & 0.00 & 1.00 \\
log real per capita GDP & 6.63 & 7.04 & 0.92 & 5.07 & 9.24 \\
Mean Light Density & 0.18 & 0.02 & 0.89 & 0.00 & 25.14 \\
DHS Survey Year & 2008.58 & 2010.00 & 4.19 & 1999.00 & 2014.00 \\
Anemia & 0.40 & 0.00 & 0.49 & 0.00 & 1.00 \\
Diarrhea & 0.15 & 0.00 & 0.36 & 0.00 & 1.00 \\
\hline Observations & 3781758 & & & & \\
\hline \hline
\end{tabular}

Table 2: Descriptive Statistics of the Country and Pixel Level Data

The Regression Discontinuity design (RD) graphs show the results of estimating equation (1) for the three outcome variables: neonatal mortality, post-neonatal and infant mortality. The first RDD figure demonstrates the difference between neonatal mortality under the civil and common law regimes. There seems to be a "jump" along the border

of countries with common law regime. This jump illustrates that the neonatal mortality under civil law is much less than that under common law. Nevertheless, figure 2 that has the post-neonatal mortality as the dependent variable shows the same jump as in figure 1 but with an opposite direction; unlike in the case of neonatal mortality, the post-neonatal mortality seemed to be much more prevalent under civil law 
than under common law. Figure 3 shows the impact of legal origins on infant mortality depicts that there is little to no jump between the countries with different legal origins thus, there seems to be no effect of legal origins on infant mortality.

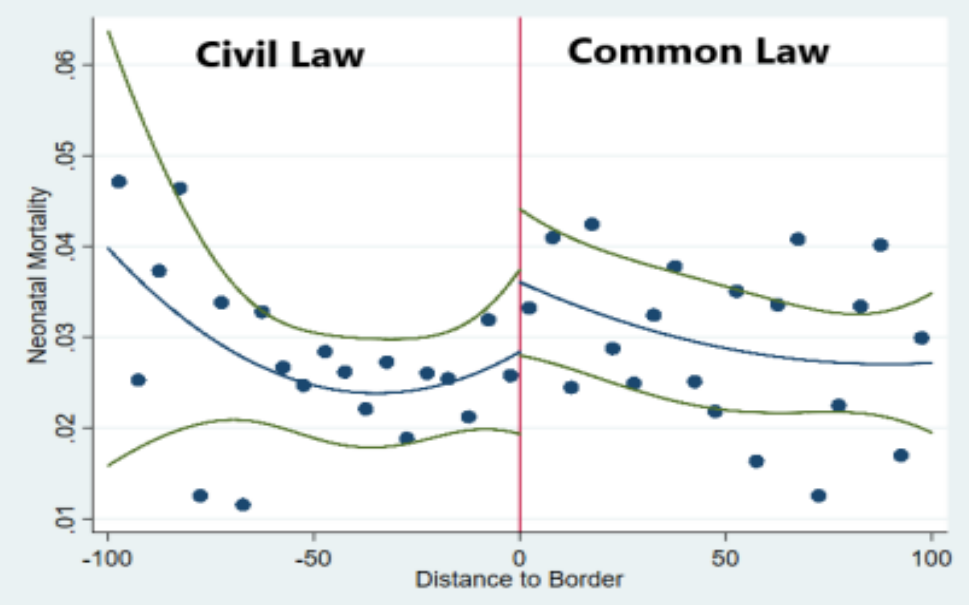

Figure 1: Neonatal Mortality RDD

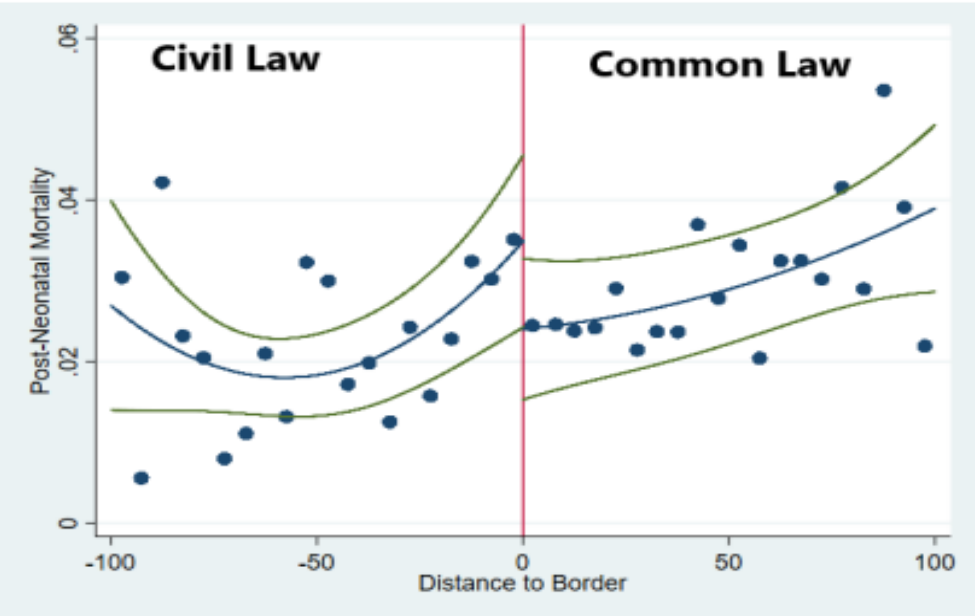

Figure 2: Post-Neonatal Mortality RDD

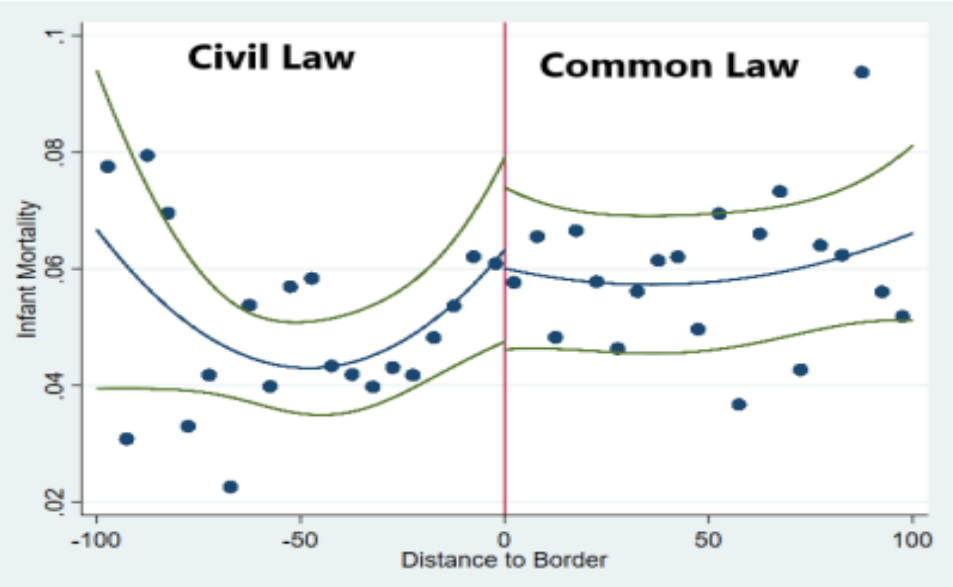

Figure 3: Infant Mortality RDD 
As per Table 3, the dependent variable being studied is the neonatal mortality that is the death of a child within the first few weeks of birth. It can be inferred from table 3 that the number of observations within $200 \mathrm{Km}, 150 \mathrm{~km}$ and $100 \mathrm{~km}$ from the boundaries of another country are 469,488; 424,750 and 358,251 respectively, the number of observations being studied decreases the more we get closer to the national borders. Similarly, the effect of common law that is the variable of interest on child mortality within $200 \mathrm{Km}, 150 \mathrm{~km}$, and $100 \mathrm{~km}$ from the boundaries of another country are $-0.0011,-0.0038$ and 0.00339 respectively. In other words, being under a common law regime results in less incidents of neonatal mortality. However, the common law variable is not significant within the different ranges of distances from the border while other variables seemed to have a more important and significant impact on neonatal mortality. For in- stance, the birth order variable has a value of $0.0025,0.0027$ and 0.0028 respectively for the observations within $200 \mathrm{~km}, 150 \mathrm{~km}$ and $100 \mathrm{~km}$, this variable is significant at the 10 percent level. Other variables such as the existence of a petroleum field, the region in which the individuals reside if it is the south or the east seem to be much more important in determining the neonatal mortality in the sub-Saharan African region.

\begin{tabular}{|c|c|c|c|}
\hline Variable & below $200 \mathrm{Km}$ & below $150 \mathrm{~km}$ & below $100 \mathrm{Km}$ \\
\hline Common Law & $\begin{array}{c}-0.00115 \\
(-0.20)\end{array}$ & $\begin{array}{c}-0.00389 \\
(-0.66)\end{array}$ & $\begin{array}{c}-0.00337 \\
(-0.54)\end{array}$ \\
\hline Mother's Age & $\begin{array}{l}0.0000693 \\
(0.24)\end{array}$ & $\begin{array}{c}0.0000325 \\
(0.11)\end{array}$ & $\begin{array}{c}-0.000458 \\
(-1.38)\end{array}$ \\
\hline Ethnicity & $\begin{array}{l}0.0000144 \\
(0.24)\end{array}$ & $\begin{array}{l}0.0000237 \\
(0.36)\end{array}$ & $\begin{array}{l}0.0000575 \\
(0.87)\end{array}$ \\
\hline Birth Order & $\begin{array}{c}0.00258 \\
(1.64)\end{array}$ & $\begin{array}{c}0.00276^{*} \\
(1.65)\end{array}$ & $\begin{array}{c}0.00287^{\star} \\
(1.93)\end{array}$ \\
\hline Birth Interval & $\begin{array}{c}-0.000124 \\
(-1.12)\end{array}$ & $\begin{array}{c}-0.000162 \\
(-1.35)\end{array}$ & $\begin{array}{c}-0.0000495 \\
(-0.48)\end{array}$ \\
\hline Mother's Uneducated & $\begin{array}{c}0.00215 \\
(0.38)\end{array}$ & $\begin{array}{c}0.00171 \\
(0.28)\end{array}$ & $\begin{array}{l}0.0000354 \\
(0.01)\end{array}$ \\
\hline Distance to Capital & $\begin{array}{l}-0.0113 \\
(-1.44)\end{array}$ & $\begin{array}{l}-0.0124 \\
(-1.46)\end{array}$ & $\begin{array}{c}-0.00559 \\
(-0.50)\end{array}$ \\
\hline Distance to Border & $\begin{array}{c}-0.00370 \\
(-0.19)\end{array}$ & $\begin{array}{c}-0.00370 \\
(-0.18)\end{array}$ & $\begin{array}{l}-0.0183 \\
(-0.82)\end{array}$ \\
\hline Distance to sea & $\begin{array}{c}0.0178^{*} \\
(1.68)\end{array}$ & $\begin{array}{c}0.0176 \\
(1.52)\end{array}$ & $\begin{array}{c}0.00606 \\
(0.38)\end{array}$ \\
\hline Malaria Suitability & $\begin{array}{c}-0.00204 \\
(-0.19)\end{array}$ & $\begin{array}{l}-0.00569 \\
(-0.47)\end{array}$ & $\begin{array}{c}0.00301 \\
(0.21)\end{array}$ \\
\hline Diamond Mine & $\begin{array}{c}0.00573 \\
(0.71)\end{array}$ & $\begin{array}{c}0.00565 \\
(0.63)\end{array}$ & $\begin{array}{c}-0.00166 \\
(-0.17)\end{array}$ \\
\hline Petroleum Field & $\begin{array}{l}-0.0214^{* *} \\
(-2.28)\end{array}$ & $\begin{array}{c}-0.0234^{* *} \\
(-2.33)\end{array}$ & $\begin{array}{c}-0.0319^{* * *} \\
(-2.71)\end{array}$ \\
\hline $\begin{array}{l}\text { Land Suitability for Agicul- } \\
\text { ture }\end{array}$ & -0.0106 & -0.0152 & -0.00770 \\
\hline & $(-0.64)$ & $(-0.83)$ & $(-0.39)$ \\
\hline Mean Elevation & $\begin{array}{c}-0.00704 \\
(-1.21)\end{array}$ & $\begin{array}{c}-0.00948 \\
(-1.46)\end{array}$ & $\begin{array}{c}-0.00892 \\
(-1.25)\end{array}$ \\
\hline Land Area & $\begin{array}{c}-0.0000616 \\
(-0.58)\end{array}$ & $\begin{array}{c}-0.0000693 \\
(-0.62)\end{array}$ & $\begin{array}{c}-0.0000259 \\
(-0.21)\end{array}$ \\
\hline Region: South & $\begin{array}{r}0.0284 \\
(1.61)\end{array}$ & $\begin{array}{c}0.0383^{* *} \\
(2.13)\end{array}$ & $\begin{array}{c}0.0351^{* *} \\
(2.25)\end{array}$ \\
\hline Region: East & $\begin{array}{l}0.0268^{* *} \\
(2.43)\end{array}$ & $\begin{array}{l}0.0312^{* * *} \\
(2.65)\end{array}$ & $\begin{array}{c}0.0250^{* *} \\
(2.23)\end{array}$ \\
\hline Region: Center & $\begin{array}{c}0.00166 \\
(0.23)\end{array}$ & $\begin{array}{c}0.00478 \\
(0.58)\end{array}$ & $\begin{array}{c}0.00586 \\
(0.56)\end{array}$ \\
\hline Mean Light Density & $\begin{array}{c}-0.000359 \\
(-0.13)\end{array}$ & $\begin{array}{c}-0.000395 \\
(-0.12)\end{array}$ & $\begin{array}{c}0.000536 \\
(0.16)\end{array}$ \\
\hline DHS year & $\begin{array}{c}-0.000900^{* *} \\
(-2.34)\end{array}$ & $\begin{array}{c}-0.000971^{* *} \\
(-2.12)\end{array}$ & $\begin{array}{c}-0.000207 \\
(-0.59)\end{array}$ \\
\hline Distance to Border Polynom & $\begin{array}{c}-0.000000205 \\
(-1.05)\end{array}$ & $\begin{array}{c}-0.000000118 \\
(-0.26)\end{array}$ & $\begin{array}{c}-0.00000216^{* * *} \\
(-3.53)\end{array}$ \\
\hline Observations & 469488 & 424750 & 358251 \\
\hline
\end{tabular}

Table 3: Dependent Variable: Neonatal Mortality

The effect of the common law dummy variable on the post-neonatal mortality dependent variable is represented in table 4 . Unlike in the neonatal mortality case in table 3, the closer the distance to the border, the higher the incidents of post-neonatal mortality. The idea is as follows, the fact that a state falls under a common law regime will lead to a decrease in post-neonatal mortality by $-0.0105,-0.0129$ and -0.0177 respectively for a $200 \mathrm{~km}$, a $150 \mathrm{~km}$ and a $100 \mathrm{~km}$ distance from the borders. The coefficients of the variable of interest common law are all significant meaning that the legal origins do have an impact on post-neonatal mortality. Moreover, there are some control variables that equally have a strong impact on post-neonatal mortality that are the mother's age, and the birth order of the children. These two variables 
have a negative and significant impact on post-neonatal mortality under the different distance threshold from the neighbouring countries under 1 percent significance level. The environmental factors that consist of malaria suitability index, land suitability for agriculture, diamond mine, the average light density, petroleum fields as well as the distance to the border polynomial do have an instrumental impact on postneonatalmortality.

\begin{tabular}{|c|c|c|c|}
\hline Independent Variable & below $200 \mathrm{Km}$ & below $150 \mathrm{~km}$ & below $100 \mathrm{Km}$ \\
\hline Common Law & $\begin{array}{c}-0.0105 \\
(-1.66)\end{array}$ & $\begin{array}{c}-0.0129 \\
(-1.86)\end{array}$ & $\begin{array}{r}-0.0177 \\
(-2.11)\end{array}$ \\
\hline Mother's Age & $\begin{array}{c}-0.00152 \\
(-3.15)\end{array}$ & $\begin{array}{c}-0.00157 \\
(-2.89)\end{array}$ & $\begin{array}{c}-0.00133 \\
(-2.55)\end{array}$ \\
\hline Ethnicity & $\begin{array}{l}0.0000435 \\
(0.92)\end{array}$ & $\begin{array}{l}0.0000578 \\
(1.11)\end{array}$ & $\begin{array}{l}0.0000270 \\
(0.54)\end{array}$ \\
\hline Birth Order & $\begin{array}{c}0.00524 \\
(3.37)\end{array}$ & $\begin{array}{c}0.00496 \\
(3.01)\end{array}$ & $\begin{array}{c}0.00429 \\
(2.63)\end{array}$ \\
\hline Birth Interval & $\begin{array}{c}-0.0000593 \\
(-0.68)\end{array}$ & $\begin{array}{c}-0.0000308 \\
(-0.29)\end{array}$ & $\begin{array}{c}-0.0000817 \\
(-0.72)\end{array}$ \\
\hline Mother's Uneducated & $\begin{array}{c}0.00224 \\
(0.74)\end{array}$ & $\begin{array}{c}0.00386 \\
(1.29)\end{array}$ & $\begin{array}{c}0.00537 \\
(1.65)\end{array}$ \\
\hline Distance to Capital & $\begin{array}{c}0.00774 \\
(0.84)\end{array}$ & $\begin{array}{c}0.00549 \\
(0.55)\end{array}$ & $\begin{array}{c}0.0103 \\
(1.01)\end{array}$ \\
\hline Distance to Border & $\begin{array}{r}0.0200 \\
(0.70)\end{array}$ & $\begin{array}{c}0.0151 \\
(0.52)\end{array}$ & $\begin{array}{c}0.0153 \\
(0.61)\end{array}$ \\
\hline Distance to sea & $\begin{array}{l}-0.0220 \\
(-1.54)\end{array}$ & $\begin{array}{l}-0.0185 \\
(-1.20)\end{array}$ & $\begin{array}{c}-0.0244 \\
(-1.43)\end{array}$ \\
\hline Malaria Suitability & $\begin{array}{c}0.0376 \\
(3.99)\end{array}$ & $\begin{array}{c}0.0414 \\
(3.80)\end{array}$ & $\begin{array}{c}0.0414 \\
(3.25)\end{array}$ \\
\hline Diamond Mine & $\begin{array}{c}0.0157 \\
(2.27)\end{array}$ & $\begin{array}{c}0.0130 \\
(1.66)\end{array}$ & $\begin{array}{c}0.0123 \\
(1.57)\end{array}$ \\
\hline Petroleum Field & $\begin{array}{c}-0.0326 \\
(-3.07)\end{array}$ & $\begin{array}{c}-0.0359 \\
(-3.39)\end{array}$ & $\begin{array}{c}-0.0408 \\
(-3.26)\end{array}$ \\
\hline $\begin{array}{l}\text { Land Suitability for Agricul- } \\
\text { ture }\end{array}$ & 0.0374 & 0.0402 & 0.0555 \\
\hline Mean Elevation & $\begin{array}{c}-0.0168 \\
(-2.42)\end{array}$ & $\begin{array}{c}-0.0178 \\
(-2.40)\end{array}$ & $\begin{array}{c}-0.0148 \\
(-2.00)\end{array}$ \\
\hline Land Area & $\begin{array}{c}-0.000236 \\
(-2.40)\end{array}$ & $\begin{array}{c}-0.000208 \\
(-2.03)\end{array}$ & $\begin{array}{c}-0.000231 \\
(-2.26)\end{array}$ \\
\hline Region: South & $\begin{array}{c}0.0958 \\
(3.50)\end{array}$ & $\begin{array}{l}0.125 \\
(3.58)\end{array}$ & $\begin{array}{l}0.130 \\
(2.69)\end{array}$ \\
\hline Region: East & $\begin{array}{l}0.0106 \\
(1.07)\end{array}$ & $\begin{array}{c}0.0148 \\
(1.29)\end{array}$ & $\begin{array}{c}0.0152 \\
(1.14)\end{array}$ \\
\hline Region: Center & $\begin{array}{c}0.0189 \\
(3.82)\end{array}$ & $\begin{array}{c}0.0227 \\
(4.14)\end{array}$ & $\begin{array}{c}0.0247 \\
(4.27)\end{array}$ \\
\hline Mean light density & $\begin{array}{c}0.00599 \\
(1.92)\end{array}$ & $\begin{array}{c}0.0150 \\
(4.03)\end{array}$ & $\begin{array}{c}0.0194 \\
(4.26)\end{array}$ \\
\hline DHS year & $\begin{array}{c}-0.00154 \\
(-4.13)\end{array}$ & $\begin{array}{c}-0.00175 \\
(-4.05)\end{array}$ & $\begin{array}{c}-0.00162 \\
(-3.89)\end{array}$ \\
\hline Distance to Border Polynom & $\begin{array}{c}-0.000000154 \\
(-0.75)\end{array}$ & $\begin{array}{c}0.000000531 \\
(1.19)\end{array}$ & $\begin{array}{c}0.000000977 \\
(1.12)\end{array}$ \\
\hline Observations & 469488 & 424750 & 358251 \\
\hline \multicolumn{4}{|c|}{$\begin{array}{l}\text { t statistics in parentheses } \\
\text { Standard errors are clustered using the approach of Cameron, Gelbach, and Miller (2011) at the ethnic and country levels } \\
\text { Other controls include: the mode of marriage (monogamy or polygamy), domestic organization, subsistence economy, Jurisdiction beyond } \\
\text { the local level }\end{array}$} \\
\hline
\end{tabular}

Table 4: Dependent Variable: Post-Neonatal Mortality

Table 5 depicts the effect of the common law dummy on infant mortality. The main dummy variable common law has a negative significant magnitude with a value of $-0.0116,-0.0168$ and -0.0211 within 200 $\mathrm{km}, 150 \mathrm{~km}$ and $100 \mathrm{~km}$ distance from the border so, the magnitude of the variable decreases as we approach the borders indicating a de- crease in infant mortality incidents near the borders. Therefore, it can be deduced that the legal origins do have an impact on infant mortality. Nonetheless, some control variables such as mother's age and the birth order seem to have an important role with a negative and significant magnitude. For the variable indicating the mother's age, we have magnitudes of -0.00146, 0.00154 and -0.00179 for the different distances from the boundaries. While the variable of birth order 
shows a positive and significant impact of $0.00782,0.00772$ and 0.00716 for a distance within $200 \mathrm{~km}, 150$ $\mathrm{km}$, and $100 \mathrm{~km}$, respectively. Other variables that exhibit a significant impact on infant mortality include the malaria suitability index, the existence of a petroleum field, the land suitability for agriculture, the mean elevation of the land, the land area the average light density as well as the regions where the individuals reside.

\begin{tabular}{|c|c|c|c|}
\hline Independent Variable & below $200 \mathrm{Km}$ & below $150 \mathrm{~km}$ & below $100 \mathrm{Km}$ \\
\hline Common Law & $\begin{array}{c}-0.0116 \\
(-1.27)\end{array}$ & $\begin{array}{c}-0.0168 \\
(-1.70)\end{array}$ & $\begin{array}{c}-0.0211 \\
(-1.70)\end{array}$ \\
\hline Mother's Age & $\begin{array}{c}-0.00146 \\
(-2.43)\end{array}$ & $\begin{array}{c}-0.00154 \\
(-2.41)\end{array}$ & $\begin{array}{c}-0.00179 \\
(-2.81)\end{array}$ \\
\hline Ethnicity & $\begin{array}{c}0.0000579 \\
(0.73)\end{array}$ & $\begin{array}{c}0.0000815 \\
(0.97)\end{array}$ & $\begin{array}{c}0.0000846 \\
(1.00)\end{array}$ \\
\hline Birth Order & $\begin{array}{c}0.00782 \\
(4.41)\end{array}$ & $\begin{array}{c}0.00772 \\
(4.12)\end{array}$ & $\begin{array}{c}0.00716 \\
(4.00)\end{array}$ \\
\hline Birth Interval & $\begin{array}{c}-0.000183 \\
(-1.11)\end{array}$ & $\begin{array}{c}-0.000193 \\
(-1.05)\end{array}$ & $\begin{array}{c}-0.000131 \\
(-0.73)\end{array}$ \\
\hline Mother's Uneducated & $\begin{array}{c}0.00440 \\
(0.69)\end{array}$ & $\begin{array}{c}0.00557 \\
(0.83)\end{array}$ & $\begin{array}{c}0.00541 \\
(0.84)\end{array}$ \\
\hline Distance to Capital & $\begin{array}{c}-0.00355 \\
(-0.31)\end{array}$ & $\begin{array}{c}-0.00686 \\
(-0.53)\end{array}$ & $\begin{array}{c}0.00470 \\
(0.33)\end{array}$ \\
\hline Distance to Border & $\begin{array}{l}0.0163 \\
(0.47)\end{array}$ & $\begin{array}{c}0.0114 \\
(0.33)\end{array}$ & $\begin{array}{c}-0.00294 \\
(-0.08)\end{array}$ \\
\hline Distance to sea & $\begin{array}{c}-0.00419 \\
(-0.23)\end{array}$ & $\begin{array}{c}-0.000886 \\
(-0.05)\end{array}$ & $\begin{array}{l}-0.0184 \\
(-0.80)\end{array}$ \\
\hline Malaria Suitability & $\begin{array}{l}0.0355 \\
(2.32)\end{array}$ & $\begin{array}{c}0.0357 \\
(2.25)\end{array}$ & $\begin{array}{c}0.0445 \\
(2.13)\end{array}$ \\
\hline Diamond Mine & $\begin{array}{c}0.0214 \\
(2.21)\end{array}$ & $\begin{array}{l}0.0186 \\
(1.60)\end{array}$ & $\begin{array}{r}0.0107 \\
(0.77)\end{array}$ \\
\hline Petroleum Field & $\begin{array}{c}-0.0540 \\
(-3.90)\end{array}$ & $\begin{array}{c}-0.0593 \\
(-4.11)\end{array}$ & $\begin{array}{c}-0.0727 \\
(-4.52)\end{array}$ \\
\hline $\begin{array}{l}\text { Land Suitability for Agri- } \\
\text { culture }\end{array}$ & 0.0268 & 0.0250 & 0.0478 \\
\hline & $(1.18)$ & $(0.98)$ & $(2.05)$ \\
\hline Mean Elevation & $\begin{array}{c}-0.0238 \\
(-2.80)\end{array}$ & $\begin{array}{c}-0.0273 \\
(-3.11)\end{array}$ & $\begin{array}{c}-0.0237 \\
(-2.65)\end{array}$ \\
\hline Land Area & $\begin{array}{c}-0.000297 \\
(-2.24)\end{array}$ & $\begin{array}{c}-0.000278 \\
(-2.01)\end{array}$ & $\begin{array}{c}-0.000257 \\
(-1.75)\end{array}$ \\
\hline Region: South & $\begin{array}{l}0.124 \\
(3.72)\end{array}$ & $\begin{array}{l}0.164 \\
(4.36)\end{array}$ & $\begin{array}{l}0.165 \\
(3.58)\end{array}$ \\
\hline Region: East & $\begin{array}{l}0.0373 \\
(2.36)\end{array}$ & $\begin{array}{l}0.0460 \\
(2.57)\end{array}$ & $\begin{array}{c}0.0402 \\
(2.13)\end{array}$ \\
\hline Region: Center & $\begin{array}{l}0.0205 \\
(2.31)\end{array}$ & $\begin{array}{c}0.0275 \\
(2.51)\end{array}$ & $\begin{array}{c}0.0306 \\
(2.26)\end{array}$ \\
\hline Mean Light Density & $\begin{array}{c}0.00563 \\
(1.19)\end{array}$ & $\begin{array}{c}0.0146 \\
(2.81)\end{array}$ & $\begin{array}{c}0.0199 \\
(3.43)\end{array}$ \\
\hline DHS year & $\begin{array}{c}-0.00243 \\
(-4.97)\end{array}$ & $\begin{array}{c}-0.00272 \\
(-4.78)\end{array}$ & $\begin{array}{c}-0.00183 \\
(-3.48)\end{array}$ \\
\hline $\begin{array}{l}\text { Distance to Border poly- } \\
\text { nomial }\end{array}$ & -0.000000359 & 0.000000413 & -0.00000119 \\
\hline & $(-1.50)$ & $(0.74)$ & $(-1.01)$ \\
\hline Observations & 469488 & 424750 & 358251 \\
\hline \multicolumn{4}{|c|}{$\begin{array}{l}\text { t statistics in parentheses } \\
\text { Standard errors are clustered using the approach of Cameron, Gelbach, and Miller (2011) at the ethnic and country levels } \\
\text { Other controls include: the mode of marriage (monogamy or polygamy), domestic organization, subsistence economy, Jurisdiction beyond } \\
\text { the local level }\end{array}$} \\
\hline
\end{tabular}

Table 5: Dependent Variable: Infant Mortality

\section{Conclusion}

To unravel the possible effects of colonial legal systems on the health outcomes of the population, this research paper looks at the breakdown of infant mortality that is used as a proxy of the health stance of the inclusive population. From this study, a main conclusion is the fact that the RD design graphs of the degrees of infant mortality rates further back up the results provided in the estimated tables. This overlapping of results provides enough evidence supporting a negative relationship between the existence of a common law regime and the child mortality incidence. Out of the RD design graphs and the tables, it can be inferred that the post-neonatal mortality rates are more pervasive under civil law while infant mortality is likely to be in civil law countries. As for the neonatal mortality graph, it is more prevalent in countries adopting common law, but this is not supported by the tables' results. The postneonatal and infant mortality phenomena are more likely to occur under civil law rather than common law. However, the legal origins do not seem to have any impact on the neonatal mortality. Some considerable 
limitations were faced such as the inability to control for some variables because of a high multicollinearity issue that leads to the disappearance of the coefficients from the results. In addition to the existence of some time constraints that impeded the inclusion of robustness checks that concern the polynomial of the RD design specification. Yet, keeping only a second-order polynomial of the distance to the national border is intuitive for studying health related studies following Anderson (2018) methodology

\section{References}

The DHS Program Geospatial Covariate Datasets Manual. Guide to DHS Statistics.

IndexMundi - Country Facts.

UNICEF - UNICEF Social Inclusion, Policy and Budgeting - Importance of investing in children.

Acemoglu, D. and Johnson, S. (2003). Unbundling Institutions. National Bureau of Eco-nomic Research, (9934).

Anderson, S. (2018). Legal Origins and Female HIV. American Economic Review, 108(6):1407-1439.

Hallward-Driemeier, M. and Hasan, T. (2012). Empowering Women: Legal Rights and Economic Opportunities in Africa. Washington, DC: World Bank.

Heaton, T. B. (2015). Are Improvements in Child Health Due to Increasing Status of Women in Developing Nations? Biodemography and Social Biology, 61(3):252-265.

La Porta, R., Lopez-de Silanes, F., and Shleifer, A. (2008). The Economic Consequences of Legal Origins. Journal of Economic Literature, 46(2):285-332.

Michalopoulos, S. and Papaioannou, E. (2013). Pre-Colonial Ethnic Institutions and Con- temporary African Development. Econometrica,81(1):113-152.

Pathania, V. (2014). The impact of malaria control on infant mortality in Kenya. Economic Development and Cultural Change, 62:459-487.

Reidpath, D. D. and Allotey, P.(2003). Infant mortality rate as an indicator of population health. Journal of Epidemiology \& Community Health, 57(5):344-346.

Scanlon, C. (2016). Health Consequences of Legal Origin. Stanford Economic Journal 